\title{
Talous ohjaa oppilaitosfuusioita
}

Aaro Harju \& Leena Saloheimo. (2016). Vapaan sivistystyön oppilaitosfuusiot. PDF: www.sivistystyo.fi/doc/julkaisut/NST_ Selvitys_oppilaitosfuusiot_100117.pdf. Vapaa Sivistystyö. 89 sivua.

VAPAAN SIVISTYSTYÖN OPPILAITOKSISTA on kymmenen viime vuoden aikana laadittu lukuisia selvityksiä. Tuorein fuusioselvitys ottaa jo kansikuvallaan kantaa vapaan sivistystyön luonteeseen jokaiselle itsensä kehittämisen mahdollisuutena.

Opetus- ja kulttuuriministeriön tilaama selvitys avaa lukijan perspektiiviä: lähellä olevat ja tutut asiat saavat syvyyttä, ja oman kokemuspiirinsä voi nähdä uudesta näkökulmasta. Julkaisu on oiva käytännön lukupaketti oppilaitos- rakenteen uudistusta toteuttavalle tai suunnittelevalle ammattilaiselle, joka tarvitsee hallinnollista faktatietoa ja kollegojen kokemuksia.

Selvitys koostuu kahdesta toisiaan täydentävästä osasta, joista ensimmäinen käsittelee oppilaitosten kehitystä oppimiskeskuksiksi. Se sisältää esimerkkitapauksia vapaan sivistystyön oppilaitosten rakenteellisesta kehittämisestä. Mukana on kuusi eri puolella Suomea sijaitsevaa opistoa, joiden yhdistämisprosessit kuvataan tiivistetysti. Lopuksi

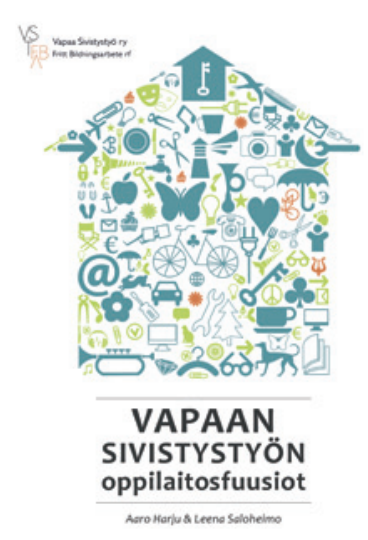

kootaan esimerkkitapausten tavoitteet ja tulokset.

Toinen osa on selvitys vapaan sivistystyön oppilaitosfuusioista ja yhteistyöverkostoista. Sen päätteeksi esitetään taulukot oppilaitosmuotorajat ylittäneistä 
rakenneratkaisuista, saman oppilaitosmuodon sisältäneistä toteutetuista rakenneratkaisuista, opistojen alueellisista yhteistyöverkostoista, Osaava-täydennyskoulutuksen yhteistyöhankkeista, hallinnollisista yhteistyöratkaisuista sekä oppilaitosten yhteisistä laatu-ja kehittämishankkeista.

\section{OPPILAITOSKENTTÄ}

\section{ON HAJANAINEN}

Julkaisun sisällysluettelo antaa viitteitä aihepiirin laajuudesta ja sirpaleisuudesta. Lukijan haasteeksi jää muodostaa kokonaiskuva vapaan sivistystyön hallinnollisesti ja toiminnallisesti hajanaisesta kentästä.

Lainsäädäntö kattaa viisi oppilaitosmuotoa, joiden omistajapohjat vaihtelevat yksityisestä kunnalliseen tai useaan kuntaan tai omistajaan. Joidenkin opistojen toimintaan vaikuttavat yhä uskonto ja politiikka. Koulutustarjonta vaihtelee ammatillisesta koulutuksesta yleissivistävään koulutukseen.

Kun opistomuotojen kirjoon lisätään toimintaympäristön muutos ja fuusiosuunnitelmat, yksittäisen opistoyksikön muutostekijöiden määrä on valtaisa. Vastaavaa muutosten myrskyä tuskin löytyy muista oppilaitosmuodoista Suomessa. Nähtäväksi jää, millaisen suunnan tulevaisuuteen vapaan sivistystyön oppilaitosten suurimmat omistajat, kunnat ja kaupungit, ottavat tulevan maakuntauudistuksen myötä.

\section{SUURIN MURROS KANSALAISOPISTOISSA}

Talouden näkökulma on selvityksen punainen lanka, tärkein oppilaitosrakenteiden uudistuksiin vaikuttava tekijä. Kun ajankohtaisin sivistyspoliittisen keskustelun kärki osuu ammatilliseen koulutukseen, selvitys näyttää marginaalissa tapahtuneen vapaan sivistystyön oppilaitosten rajun ja varsin pitkään jatkuneen reformoinnin. Lukija oppii, kuinka vapaan sivistystyön ylläpitäjä- ja oppilaitosrakenteita on uudistettu pikkuhiljaa ja huomaamatta. Sen myötä vapaan sivistystyön valtionosuudet ja -avustukset ovat vähentyneet viidessä vuodessa yli yhdeksän miljoonaa euroa.

Eri oppilaitosmuotoja on kuitenkin uudistettu eri tavoilla. Eniten muutoksia ovat kokeneet kansalaisopistot, joiden ylläpitäjien määrä on pudonnut liki 10 prosenttia vuosina 2009-2015. Valtio on kohdistanut fuusioitumis- paineitaan myös kansanopistoihin. Kesäyliopistot, liikunnan koulutuskeskukset ja opintokeskukset ovat saaneet olla varsin rauhassa rakenneuudistuksilta. Valitettavasti julkaisu ei tarjoa perusteluja tai kriittistä tarkastelua eri oppilaitosmuotojen eriarvoiselle kehitykselle.

\section{RAHOITUKSEN TURVAAMINEN TÄRKEINTÄ}

Lukijalle selviää, että aiempien selvitysten tuloksia on harvoin otettu käytäntöön. Jos tulos on osoittanut, että tulee laajentaa opistojen toimintaa tai syventää yhteistyötä muiden oppilaisten kanssa, yhteistyötä ei ole haluttu tehdä. Ylläpitäjän intressinä ei ole yhteistyö vaan oman opiston pitäminen hengissä, tärkeimpänä valtion rahoituksen turvaaminen.

Selvitys on verkossa avoimesti luettavissa. Julkaisun kansainvälisen levitettävyyttä parantaisi, jos tulokset sidottaisiin meneillään olevaan laajaan yhteiskunnalliseen muutokseen ja ne olisivat luettavissa myös englanniksi.

TARJA LANG

FT, tutkimuspäällikkö

Omnia Koulutus 